\title{
Kinetics of improved 1,4-alpha-D-glucan glucohydrolase biosynthesis from a newly isolated Aspergillus oryzae IIB-6 and parameter significance analysis by 2 -factorial design
}

\author{
Bilqees Fatima and Sikander Ali
}

\begin{abstract}
Sixteen different mould cultures viz. Aspergillus, Alternaria, Arthroderma, Trichoderma, Fusarium, Penicillium, Rhizopus and Chochliobolus were isolated from the soil samples of Qatar by serial dilution method. The preliminary screening of isolates was done by selecting initial colonies showing relatively bigger zones of starch hydrolysis on nutrient agar plates. The isolates were then subjected to secondary screening by submerged fermentation (SmF). The 1,4-a-D-glucan glucohydrolase (GGH) activity ranged from 1.906-12.675 U/ml/min. The product yield was analysed in dependence of mycelial morphology, biomass level and protein content. The isolate Aspergillus oryzae IIB-6 which gave maximum enzyme production was incubated in $\mathrm{M} 3$ medium containing $20 \mathrm{~g} / \mathrm{l} \mathrm{starch}, 10 \mathrm{~g} / \mathrm{l}$ lactose, $8.5 \mathrm{~g} / \mathrm{l}$

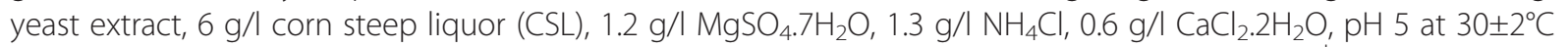
and $200 \mathrm{rpm}$. On the basis of kinetic variables, notably $Q_{p}\left(0.058 \pm 0.01^{\mathrm{a}} \mathrm{U} / \mathrm{g} / \mathrm{h}\right), \mathrm{Y}_{\mathrm{p} / \mathrm{s}}\left(0.308 \pm 0.03^{\mathrm{ab}} \mathrm{U} / \mathrm{g}\right)$ and $\mathrm{q}_{\mathrm{p}}$ $\left(0.210 \pm 0.032^{\mathrm{abc}} \mathrm{U} / \mathrm{g}\right.$ fungal biomass $\left./ \mathrm{h}\right)$, A. oryzae IIB-6 was found to be a hyper producer of GGH (LSD 0.0345)

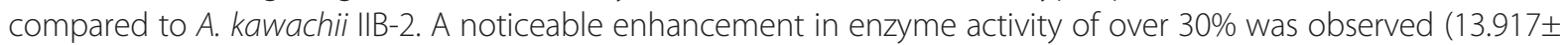
$1.01 \mathrm{U} / \mathrm{ml} / \mathrm{min}$ ) when the process parameters viz. cultural conditions ( $\mathrm{pH}$, incubation period $72 \mathrm{~h}$ ) and nutritional requirements ( $6 \mathrm{~g} / \mathrm{l} \mathrm{CSL}, 9.5 \mathrm{~g} / \mathrm{l}$ yeast extract, $10 \mathrm{~g} / \mathrm{l}$ starch, $20 \mathrm{~g} / \mathrm{l}$ lactose) were further optimized using a 2-factorial Plackett-Burman design. The model terms were found to be highly significant ( $H S, p \leq 0.05)$, indicating the potential utility of the culture (dof 3).
\end{abstract}

Keywords: Aspergillus oryzae, Batch-culture, 2-factorial design, Glucoamylase, Kinetics, Mould culture

\section{Background}

The enzyme 1,4- $\alpha$-D-glucan glucohydrolase (GGH, EC 3.2.1.3) is an exo-amylase which cleaves both $\alpha-1,4$ and $\alpha-1,6$ glycosidic bonds, yielding $\beta$-D-glucose from the non-reducing end of starch polymer chain. GGH degrades starch to glucose in theoretically $100 \%$ yields. The reaction rate decreases with the decreasing chain length of the dextrin substrate. The enzyme is also capable of catalysing a reverse of the normal hydrolysis reaction to produce mainly maltose and isomaltose (Rangabhashiyam et al. 2011). It has wide range of applications in industries for the production of dextrose, high-fructose corn syrup (HFCS) and ethanol (Rubinder

\footnotetext{
* Correspondence: alisbiotech@yahoo.com

Institute of Industrial Biotechnology (IIB), GC University Lahore, H.30, St.7, Tezab Ahata, Lahore-39, Pakistan
}

et al. 2002). With the advent of new frontiers in biotechnology, the spectrum of enzyme applications has widened in many other fields, such as clinical, medicinal and analytical chemistries, and in textile, food, detergent, paper, backing, wine, brewing, distilling and fine chemical industries. Earlier, it was considered that plant and animal materials were the best sources of enzymes. Nowadays, however, microbial enzymes are becoming increasingly important for their technical and economic advantages (Kelly and Fogarty 1976; Kumar and Satyanarayana 2009). A diverse group of microorganisms has been reported to produce the enzyme. However, commercial enzyme has traditionally been produced by employing filamentous fungi, since they secrete large quantities of extracellular enzyme. The production of an active enzyme depends on the selection of a suitable mould for the purpose. Fungal 
GGH contains both starch binding and catalytic binding domains, the former being responsible for activity on raw starch (Karaoglu and Ulker 2006). The soil is known to be a repository of fungal amylase producers; Aspergillus, Penicillium, Trichoderma, Fusarium and Rhizopus spp. have been isolated and characterized. However, not even a single comprehensive report has appeared in the available literature dealing with the growth kinetics, mycelial morphology and parametric significance analysis through statistical factorial design. Furthermore, it is also imperative to screen useful fungi for manufacturing of desired product (Oshoma et al. 2010).

The methods of cultivation greatly influence the production and properties of the enzyme. The most common methods of production involve either solid state (SSF) or submerged fermentation (SmF). Traditionally, GGH has been produced by the later processes as enzyme production was about 5 fold higher than with the former (Pandey et al. 2000). The conditions of fermentation such as growth period, temperature, $\mathrm{pH}$, agitation and aeration and medium composition greatly affect the enzyme production under SmF. In SmF, the morphology of filamentous microorganisms varies between two extreme forms, pellets and free filaments, depending on culture conditions and the genotype of the strain. According to previous reports, mycelial morphology is crucial to the process of fermentation, not only in relation to the shape of the hyphae themselves and the aggregation into microscopic clumps (micro-morphology), but also in the pelleted form of growth (macro-morphology). However, reports on the preferred morphology are often contradictory since each one of the two extreme forms pellets vs. filaments - has their own characteristics concerning cell physiology, growth kinetics, nutrient consumption and broth rheology, which can be regarded either as advantages or as drawbacks (Clementi and Rossi 1986; Papagianni 2004). The present study is concerned with screening of mould cultures, isolated from soil, for the production and optimization of cultural conditions for GGH being carried out aseptically from the selected species and their morphological changes. The 2-factorial Plackett-Burman experimental design was used to further identify the significant batch culture conditions influencing enzyme productivity.

\section{Results and discussion}

In the present studies, sixteen different soil inhabited mould cultures were isolated and screened for GGH production under SmF (Table 1). The enzyme activity and DCM ranged from 1.906-12.675 U/ml/min and 7.236-15.803 g/l, respectively. The maximum enzyme activity $(12.675 \pm 1 \mathrm{U} / \mathrm{ml} / \mathrm{min})$ was obtained with IIB-6 and it was identified as Aspergillus oryzae. This enzyme value varied significantly $(\mathrm{p} \leq 0.05)$ than the other species except A. kawachii (IIB-2). The DCM was $13.045 \pm 1.413 \mathrm{~g} / \mathrm{l}$ while protein content was recorded to be $73.343 \pm 1.522$ $\mu \mathrm{g} / \mathrm{ml}$. Therefore, the isolates $A$. oryzae IIB-6 and $A$. kawachii IIB-2, being hyper producers of GGH were selected for kinetic comparison. A diversified mycelial morphology was noticed with other cultures however, A. oryzae IIB-6 exhibited mixed kind of mycelia. The product yield was analysed independent of mycelial morphology or pellet size, biomass concentration and protein content as reported by Kelly and Fogarty (1976). Razzaque and Ueda (1978) worked on Aspergillus spp. and were also selected one strain of $A$. oryzae RIB-40 as the best GGH producer. Similarly, ten strains of $A$. flavus, two strains of $A$. tamarii and one of each $A$. niger and $A$. awamori were found to be promising producer among all isolates of soil of Kusmi forest (Morya and Yadav 2009). Fourteen Aspergillus isolates from soil were chosen as hyper producers by Abdalwahab et al. (2012).

The kinetic parameters viz. specific growth rate $(\mu)$, product formation parameters $\left(\mathrm{Q}_{\mathrm{p}}, \mathrm{Y}_{\mathrm{p} / \mathrm{s}}, \mathrm{Y}_{\mathrm{p} / \mathrm{x}}, \mathrm{q}_{\mathrm{p}}\right)$ and substrate consumption variables $\left(\mathrm{Y}_{\mathrm{x} / \mathrm{s}}, \mathrm{Q}_{\mathrm{s}}, \mathrm{q}_{\mathrm{s}}, \mathrm{Q}_{\mathrm{x}}\right)$ were compared for two hyper producing isolates i.e., $A$. kawchii IIB-2 and $A$. oryzae IIB-6 (Table 2). The comparison of $\mathrm{Q}_{\mathrm{s}}$ (g biomass/L/h) for enzyme productivity demonstrated that isolate IIB- 6 has a higher value for volumetric rate of substrate consumption $\left(\mathrm{Q}_{\mathrm{s}}=0.268 \pm 0.03^{\mathrm{a}} \mathrm{g} / \mathrm{l} / \mathrm{h}\right)$ than IIB-2 $\left(0.212 \pm 0.021^{\mathrm{bc}} \mathrm{g} / \mathrm{l} / \mathrm{h}\right)$. A several fold $(\sim 10)$ improvement in terms of volumetric enzyme productivity was noted with the former at all the rates examined. Although IIB-2 achieved a higher value $\left(\mathrm{Y}_{\mathrm{x} / \mathrm{s}}=1.124 \pm\right.$ $\left.0.221^{\mathrm{ab}} \mathrm{g} \mathrm{DCM} / \mathrm{g}\right)$ than IIB-6 $\left(1.065 \pm 0.113^{\mathrm{bc}} \mathrm{g} \mathrm{DCM} / \mathrm{g}\right)$, however the later demonstrated a significant improvement $(\mathrm{p} \leq 0.05)$ in volumetric rate of product formation. In addition, when both of the mould isolates were monitored for specific rate constant, IIB- 6 gave higher values for $\mathrm{q}_{\mathrm{p}}$ (greater than $45 \%$ improvement). Hence, $A$. oryzae IIB-6 exhibited an overall 5 to 8 fold improvement in the values for $\mathrm{Q}_{\mathrm{p}}, \mathrm{Y}_{\mathrm{p} / \mathrm{x}}, \mathrm{Y}_{\mathrm{p} / \mathrm{s}}$ and $\mathrm{q}_{\mathrm{p}}$ over the A. kawchii IIB-2 ( $L S D \sim 0.034$ ) which is highly significant (HS) and this was supported by the findings reported by (Pirt 1975). Goto et al. (1998) found that nutritional parameters influence the substrate consumption rate, specific growth rate and subsequent GGH productivity. The kinetic values of the enzyme demonstrate that GGH is an exo- rather than an endo- mode as it has higher affinity for the starch rather than other oligo- or polysaccharide polymers.

Among various fermentation media, maximal GGH production $(12.609 \pm 0.899 \mathrm{U} / \mathrm{ml} / \mathrm{min}, \mathrm{LSD} 2.651)$ was obtained when M3 was used (Table 3). It was due to the fact that enzyme production is strongly influenced by the organic carbon and nitrogen sources as reported by Bertolin et al. (2003). Furthermore, M3 has an adequate 
Table 1 Screening of different mould cultures for GGH production in submerged fermentation*

\begin{tabular}{|c|c|c|c|c|c|c|}
\hline \multicolumn{2}{|c|}{ Mould cultures } & \multirow{2}{*}{$\begin{array}{l}\text { Protein content } \\
(\mu \mathrm{g} / \mathrm{ml})\end{array}$} & \multirow{2}{*}{$\begin{array}{l}\text { Enzyme activity } \\
\text { (U/ml/min) }\end{array}$} & \multirow[t]{2}{*}{$\mathrm{DCM}(\mathrm{g} / \mathrm{l})$} & \multirow{2}{*}{$\begin{array}{l}\text { Mycelial } \\
\text { morphology** }\end{array}$} & \multirow[t]{2}{*}{ Cited bibliography } \\
\hline Isolated strains & Coding & & & & & \\
\hline Aspergillus spp. & $\| \mathrm{B}-1$ & $30 \pm 0.997$ & $8.831 \pm 0.974$ & $13.131 \pm 0.612$ & Dumpy mass & Papagianni (2004) \\
\hline Aspergillus kawachii & $\| B-2$ & $30.341 \pm 0.574$ & $12 \pm 0.987$ & $12.243 \pm 0.926$ & Large pellets & Shoji et al. (2007) \\
\hline Chochliobolus spp. & IIB-3 & $64.672 \pm 0.521$ & $2.341 \pm 0.936$ & $7.232 \pm 0.231$ & Gelatinous & Norouzian et al. (2006) \\
\hline Aspergillus niger & $\| B-4$ & $73.675 \pm 0.525$ & $4.343 \pm 0.986$ & $12.523 \pm 0.824$ & Viscous & Kelly and Fogarty (1976) \\
\hline Aspergillus flavus. & $\| B-5$ & $16.671 \pm 0.572$ & $11.523 \pm 0.525$ & $12.161 \pm 0.632$ & Mixed & (Gomes et al. 2005) \\
\hline Aspergillus oryzae & $\| B-6$ & $73.343 \pm 0.524$ & $12.673 \pm 0.998$ & $13.044 \pm 0.413$ & Mixed & Kassim (1983) \\
\hline Arthroderma spp. & $\| B-7$ & $61.661 \pm 0.521$ & $1.902 \pm 0.523$ & $10.523 \pm 0.151$ & Intermediate pellets & Norouzian et al. (2006) \\
\hline Fusarium oxysporum & $\| B-8$ & $29 \pm 0.997$ & $2.724 \pm 1.082$ & $15.812 \pm 0.145$ & Fine pellets & Karaoglu and Ulker (2006) \\
\hline Trichoderma viride & $\| B-9$ & $12 \pm 0.996$ & $1.948 \pm 1.309$ & $14.343 \pm 0.154$ & Dumpy mass & Karaoglu and Ulker (2006) \\
\hline Aspergillus fumigatus & IIB-10 & $16.342 \pm 0.522$ & $3.839 \pm 0.521$ & $12.831 \pm 0.115$ & Fine pellets & Goto et al. (1998) \\
\hline Alternaria alternata & $\| \mathrm{B}-11$ & $16.673 \pm 0.521$ & $5.343 \pm 0.997$ & $16.34 \pm 0.123$ & Dumpy mass & Norouzian et al. (2006) \\
\hline Rhizopus spp. & IIB-12 & $73 \pm 0.641$ & $10.185 \pm 0.523$ & $13.365 \pm 0.151$ & Viscous & Morita et al. (1998) \\
\hline Penicillium italicum & IIB-13 & $143 \pm 0.998$ & $2.563 \pm 0.524$ & $13.845 \pm 0.123$ & Viscous & Nandi and Mukherjee (1989) \\
\hline Aspergillus candidus & ||B-14 & $12.672 \pm 1.052$ & $7.943 \pm 0.932$ & $10.232 \pm 0.221$ & Fine pellets & Narayanan and Ambedkar (1993) \\
\hline Aspergillus awamori & IIB-15 & $10 \pm 0.997$ & $4.684 \pm 0.975$ & $8.634 \pm 0.152$ & Small pellets & Bertolin et al. (2003) \\
\hline Aspergillus foetidus & IIB-16 & $10 \pm 0.993$ & $5.362 \pm 0.521$ & $9.823 \pm 0.161$ & Small pellets & Michelena and Castillo (1984) \\
\hline
\end{tabular}

* Incubation was carried out for $72 \mathrm{~h}$ with agitation intensity $200 \mathrm{rpm}$ at temperature and $\mathrm{pH} 30 \pm 2^{\circ} \mathrm{C}$ and 5 , respectively. ${ }^{*}$ Foundation of fungal macro-morphology have been laid down in methods section. Y-error bars indicate the standard deviation ( \pm S.D) among the three parallel replicates. The values in each set differ significantly at $p \leq 0.05$.

Table 2 Comparison of various kinetic parameters for GGH productivity by $A$. kawachii (IIB-2) and $A$. oryzae (IIB-6) at $\mathbf{7 2} \mathrm{h}$ of fermentation*

\begin{tabular}{|c|c|c|}
\hline \multirow[t]{2}{*}{ Kinetic parameters } & \multicolumn{2}{|c|}{ Hyper producing fungal isolates } \\
\hline & IIB-2 & IIB-6 \\
\hline \multicolumn{3}{|l|}{ Specific growth rate } \\
\hline$\mu\left(h^{-1}\right)$ & $0.212 \pm 0.121^{\mathrm{ab}}$ & $0.196 \pm 0.023^{a}$ \\
\hline \multicolumn{3}{|l|}{ Enzyme production variables } \\
\hline $\mathrm{Q}_{\mathrm{p}}(\mathrm{U} / \mathrm{ml} / \mathrm{h})$ & $0.032 \pm 0.022^{\text {cde }}$ & $0.058 \pm 0.012^{a}$ \\
\hline$Y_{p / s}(U / m l / g)$ & $0.124 \pm 0.0122^{\text {def }}$ & $0.308 \pm 0.031^{\mathrm{ab}}$ \\
\hline$Y_{p / x}(U / m l / g)$ & $1.625 \pm 0.051^{\mathrm{defg}}$ & $2.455 \pm 0.552^{a}$ \\
\hline$q_{p}(U / g$ fungal biomass/h) & $0.008 \pm 0.002^{\mathrm{de}}$ & $0.210 \pm 0.032^{\mathrm{abc}}$ \\
\hline \multicolumn{3}{|l|}{ Substrate consumption variables } \\
\hline$Y_{x / s}(g$ fungal biomass/g) & $1.124 \pm 0.23^{\mathrm{ab}}$ & $1.065 \pm 0.112^{b c}$ \\
\hline$Q_{s}(g / / / h)$ & $0.212 \pm 0.022^{b c}$ & $0.268 \pm 0.032^{a}$ \\
\hline $\mathrm{q}_{\mathrm{s}}$ (g/g fungal biomass/h) & $0.125 \pm 0.012^{b c d}$ & $0.195 \pm 0.051^{\mathrm{ab}}$ \\
\hline $\mathrm{Q}_{x}$ (g fungal biomass/l/h) & $0.142 \pm 0.021^{b c}$ & $0.216 \pm 0.021^{a}$ \\
\hline Least significant difference (LSD) & 0.087 & 0.034 \\
\hline Significance level $<p>$ & S & $\mathrm{HS}$ \\
\hline
\end{tabular}

* Kinetic parameters: $\mu\left(h^{-1}\right)=$ specific growth rate, $Q_{p}=U / m l / h, Y_{p / s}=U / m l / g$ substrate consumed, $Y_{p / x}=U / m l / g$ fungal biomass formed, $q_{p}=U / g$ fungal biomass $/ \mathrm{h}, \mathrm{Y}_{\mathrm{x} / \mathrm{s}}=\mathrm{g}$ fungal biomass $/ \mathrm{g}$ substrate utilized, $\mathrm{Q}_{\mathrm{s}}=\mathrm{g}$ substrate consumed $/ / / h, q_{s}=g$ substrate consumed $/ g$ fungal biomass $/ h, Q_{x}=g$ fungal biomass formed/L/h. HS denotes 'highly significant' while $S$ stands for 'significant' values. LSD represents 'least significant difference'. $\langle p\rangle$ is for probability. \pm Indicates standard deviation among three parallel replicates. The values designated by different letters in each row differ significantly at $p \leq 0.05$. amount of $\mathrm{C} / \mathrm{N}$ sources compared to M1, M2, M4, and M5. Protein content and DCM were $73.287 \pm 1.521 \mu \mathrm{g} / \mathrm{ml}$ (LSD 0.267) and 12.967 $\pm 0.912 \mathrm{~g} / \mathrm{l}$ (LSD 1.723), respectively. Mixed mycelial pellets were observed in the broth.

During the time course study (Figure 1), the enzyme production remained very low at $12 \mathrm{~h}$ of incubation $(0.709 \pm 0.989 \mathrm{U} / \mathrm{ml} / \mathrm{min})$ and it was demonstrated that the enzyme concentration was correlated with growth of the fungus (Hyland and Clayton 1992). It was increased by increasing the incubation period but upto a certain extent. Maximum enzyme production $(13.227 \pm 1.521 \mathrm{U} /$ $\mathrm{ml} / \mathrm{min}, \mathrm{LSD} 2.268$ ) was achieved $72 \mathrm{~h}$ after the inoculation. It was approximately 18.66 fold higher than the enzyme activity obtained at $12 \mathrm{~h}$. The protein content and DCM were $76 \pm 1.042 \mu \mathrm{g} / \mathrm{ml}$ (LSD 2.184) and $15.623 \pm 1.154 \mathrm{~g} / \mathrm{l}$ (LSD 0.093), respectively. The mycelial morphology was found as small pellets. Similarly, Morita et al. (1998) obtained maximum enzyme production in $72 \mathrm{~h}$ of fermentation. The enzyme activity was gradually decreased when incubation period was prolonged beyond the optimal, it was due to the depletion of nutrients and accumulation of other by products such as proteases which acted on starch binding domains causing the enzyme to lose its activity in the fermented broth. Abdalwahab et al. (2012) reported that $A$. awamori, $A$. niger and $A$. tamarii have shown maximum enzyme production after $48 \mathrm{~h}$ while $A$. terreus showed maximum performance of enzyme production after $72 \mathrm{~h}$. 
Table 3 Evaluation of fermentation medium for GGH production by A. oryzae IIB-6 in submerged fermentation*

\begin{tabular}{|c|c|c|c|c|c|c|c|}
\hline $\begin{array}{l}\text { Media } \\
(\mathrm{g} / \mathrm{l})^{* *}\end{array}$ & $\begin{array}{l}\text { Initial } \\
\mathrm{pH}\end{array}$ & Solvent (1-L) & $\begin{array}{l}\text { Protein content } \\
(\mu \mathrm{g} / \mathrm{ml})\end{array}$ & $\begin{array}{l}\text { Enzyme activity } \\
(\mathrm{U} / \mathrm{ml} / \mathrm{min})\end{array}$ & $\mathrm{DCM}(\mathrm{g} / \mathrm{l})$ & $\begin{array}{l}\text { Mycelial } \\
\text { morphology }\end{array}$ & Cited bibliography \\
\hline M1 & 4.6 & $0.01 \mathrm{~N} \mathrm{HCl}$ & $27.671 \pm 0.521$ & $3.553 \pm 0.353$ & $5.541 \pm 0.532$ & Fine pellets & Shoji et al. (2007) \\
\hline M2 & 5.5 & Deionized $\mathrm{H}_{2} \mathrm{O}$ & $63.544 \pm 0.998$ & $9.661 \pm 0.713$ & $11.612 \pm 0.872$ & Large pellets & Papagianni (2004) \\
\hline M3 & 5 & Distilled $\mathrm{H}_{2} \mathrm{O}$ & $73.284 \pm 1.523$ & $12.623 \pm 0.854$ & $12.964 \pm 0.985$ & Mixed pellets & $\begin{array}{l}\text { Michelena and Castillo (1984); } \\
\text { Malik et al. (2011) }\end{array}$ \\
\hline M4 & 7.2 & Phosphate buffer & $17.671 \pm 0.986$ & $1.852 \pm 0.734$ & $3.456 \pm 0.634$ & Intermediate pellets & Singh and Soni (2001) \\
\hline M5 & 6.4 & $\begin{array}{l}\text { Sodium } \\
\text { acetate buffer }\end{array}$ & $53.334 \pm 0.721$ & $7.171 \pm 0.532$ & $8.613 \pm 0.998$ & Fine pellets & $\begin{array}{l}\text { Morita et al. (1998); } \\
\text { Norouzian et al. (2006) }\end{array}$ \\
\hline LSD & & & 0.267 & 2.651 & 1.723 & & \\
\hline
\end{tabular}

* Incubation was carried out for $72 \mathrm{~h}$ with agitation intensity $200 \mathrm{rpm}$ at temperature and $\mathrm{pH} 30 \pm 2^{\circ} \mathrm{C}$ and 5 , respectively.

** Media composition is given in the methods section. The constiuents of optimized medium (M3) were further designed in our labs at IIB and have previously been well exploited.

\pm indicate the standard deviation (S.D) among the three parallel replicates. The values in each set differ significantly at $p \leq 0.05$.

In another study, incubation period of $96-120 \mathrm{~h}$ was optimized by Kumar and Satyanarayana (2007).

GGH activity was not encouraging at pH 4 (5.911 \pm $1.031 \mathrm{U} / \mathrm{ml} / \mathrm{min}$ ) be due to the fact that an acidic $\mathrm{pH}$ was toxic to the mycelia of $A$. oryzae resulting in the inhibition of GGH production. The maximum enzyme production $(13.152 \pm 1.021 \mathrm{U} / \mathrm{ml} / \mathrm{min})$ was achieved when initial $\mathrm{pH}$ was adjusted to 5 (LSD 1.715) and varied significantly than other values $(\mathrm{p} \leq 0.05)$ as depicted in Figure 2. Mixed mycelia were found in the flask. The protein content and DCM were $78 \pm 1.723 \mu \mathrm{g} / \mathrm{ml}$ (LSD 2.889) and 14.922 $\pm 1.061 \mathrm{~g} / \mathrm{l}$ (LSD 0.507), respectively. Similarly, previous workers also optimized $\mathrm{pH} 5$ for enzyme production (Mishra and Das 2002). Abdalwahab et al. (2012) was found optimum $\mathrm{pH}$ for maximum enzyme production to be 6.0 for all isolates (A. awamori, A. niger and A. tamarii) except for $A$. terreus which gave maximum

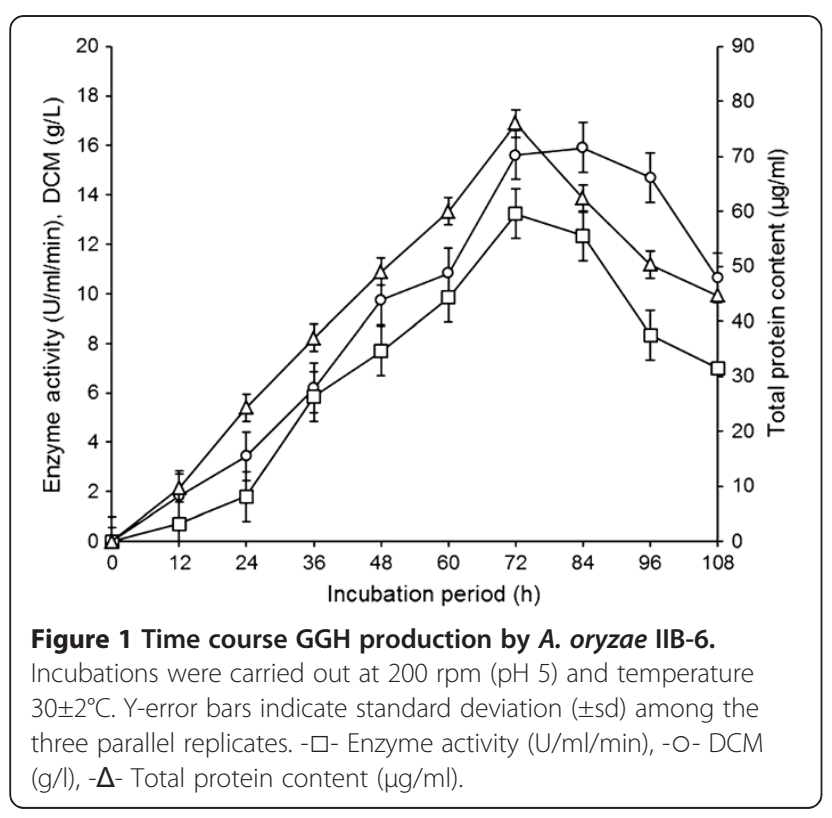

production at $\mathrm{pH}$ 4.0. A sharp decline in enzyme activity $(7.183 \pm 1.201 \mathrm{U} / \mathrm{ml} / \mathrm{min})$ was observed at $\mathrm{pH}$ 6.5. It was due to the fact that the mould required slightly acidic $\mathrm{pH}$ for its growth and subsequent enzyme production as reported earlier by Bertolin et al. (2003).

The effect of different concentrations of CSL and yeast extract on GGH production are shown in Figure 3. Maximum production was observed to be $13.263 \pm 1.501 \mathrm{U} / \mathrm{ml} /$ min when $6 \mathrm{~g} / \mathrm{l} \mathrm{CSL}$ was used in the fermentation medium (LSD 7.006), which was nearly 3.02 fold higher than control. Small pellets were observed in the fermented broth. The protein content and DCM were $74.342 \pm 1.521 \mu \mathrm{g} / \mathrm{ml}$ (LSD 5.656) and 12.974 $\pm 1.051 \mathrm{~g} / \mathrm{l}$ (LSD 0.126), respectively. Kassim (1983) used $30 \mathrm{~g} / \mathrm{l} \mathrm{CSL}$ in the fermentation medium. Therefore, our finding is economically more significant. In contrast to our study, Michelena and Castillo

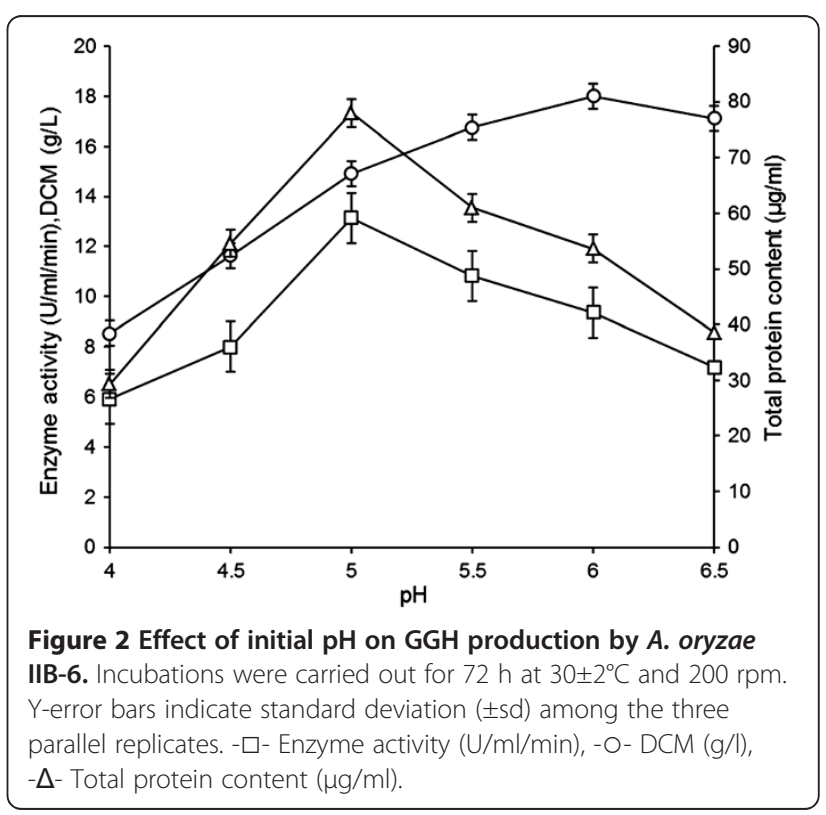



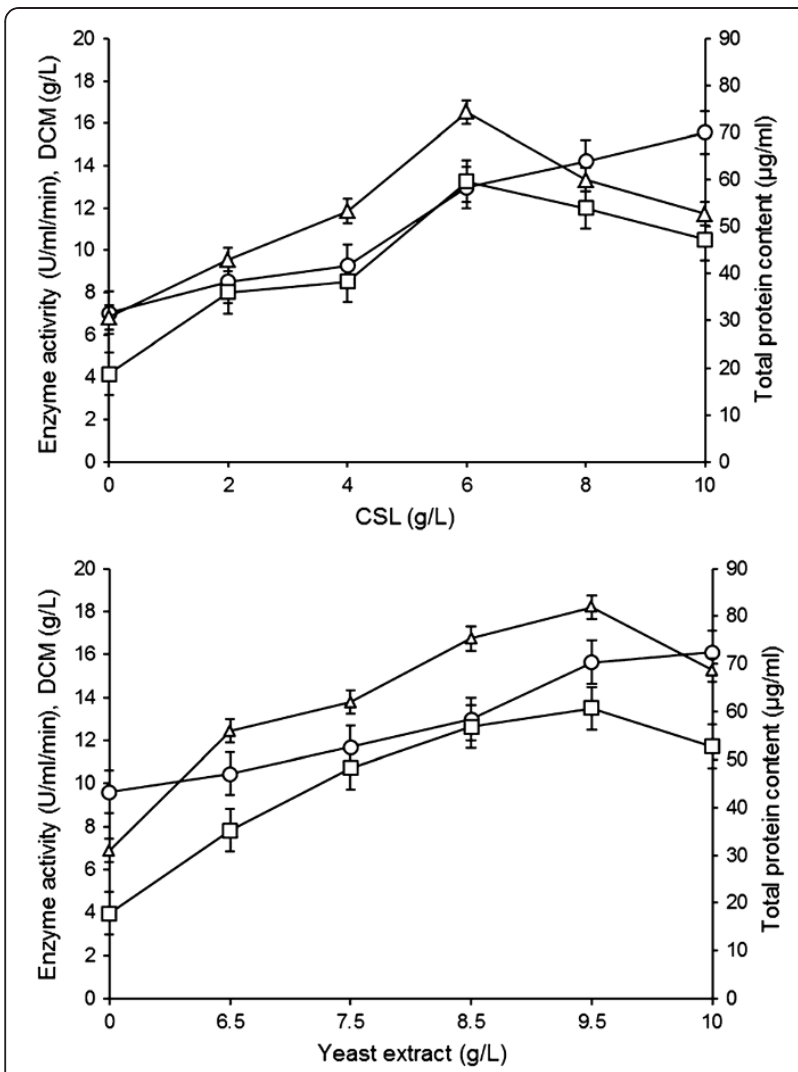

Figure 3 Effect of different concentrations of CSL and yeast extract as nitrogen sources on GGH production by $A$. oryzae IIB-6. Incubation were carried out for $72 \mathrm{~h} \mathrm{(200} \mathrm{rpm)} \mathrm{at} 30 \pm 2^{\circ} \mathrm{C}$ and $\mathrm{pH}$ 5. Y-error bars indicate standard deviation $( \pm \mathrm{sd})$ among the three parallel replicates. - $\square$ - Enzyme activity (U/ml/min), - O- DCM (g/l), $-\Delta$ - Total protein content $(\mu \mathrm{g} / \mathrm{ml})$.

(1984) optimized only $0.8 \mathrm{~g} / \mathrm{l}$ CSL for better enzyme production. Cherry et al. (2004) who reported that $A$. fumigatus produces high amylase activity with yeast extract. However, Abdalwahab et al. (2012) found that yeast extract affect negatively enzyme production by $A$. tamarii and $A$. awamori while with $A$. niger and $A$. terreus it stimulate the production. In present study, the maximum production $(13.489 \pm 1.601 \mathrm{U} / \mathrm{ml} /$ min, LSD 4.091) was obtained when $9.5 \mathrm{~g} / \mathrm{l}$ was added into the fermentation medium by $A$. oryzae. The mycelial morphology was observed as large pellets. Protein content and DCM were found to be $81.941 \pm 1.501 \mu \mathrm{g} / \mathrm{ml}(\mathrm{LSD} \sim 1.778)$ and $15.643 \pm 1.115 \mathrm{~g} / \mathrm{l}$ (LSD 0.175), respectively. Similarly, Kumar et al. (2007) observed maximum enzyme production when $10 \mathrm{~g} / \mathrm{l}$ yeast extract was used in fermentation medium. Sporangiospores secreted $41 \%$ higher GGH titres in shake flasks when $20 \mathrm{~g} / \mathrm{l}$ yeast extract was used (Oshoma et al. 2010). However, Nandi and Mukherjee (1989) reported that yeast extract (5 g/l) stimulates the production of enzyme.
Different concentrations of starch and lactose were added into the fermentation medium to induce better GGH production (Figure 4). The maximum enzyme activity $(13.184 \pm 0.991 \mathrm{U} / \mathrm{ml} / \mathrm{min})$ was noted when $10 \mathrm{~g} / \mathrm{l}$ starch was used (LSD 1.735) which was about 1.86 fold higher compared to the control. The protein content and DCM were $75.162 \pm 1.081 \mu \mathrm{g} / \mathrm{ml}$ (LSD 2.266) and $14.471 \pm 1.213 \mathrm{~g} / \mathrm{l}$ (LSD 0.287), respectively. Mycelial morphology was in the form of small pellets. Similarly, Kunamneni et al. (2005) and Arnthong et al. (2010) reported that enzyme production reached maximal when $10 \mathrm{~g} / \mathrm{l}$ starch was added in the fermentation medium. As the amount of starch was increased enzyme production was decreased which was due to carbon catabolite repression (Morita et al. 1998). However, other workes reported that $20 \mathrm{~g} / \mathrm{l}$ rice flour (as a source of starch) concentration seems to be the concentration that gave maximum production of GGH. Above $20 \mathrm{~g} / \mathrm{l}$, there was little increase in enzyme production. These results were mostly obvious in the case of $A$. niger and $A$. awamori (Abdalwahab et al. 2012). Previously, Cherry et al. (2004)

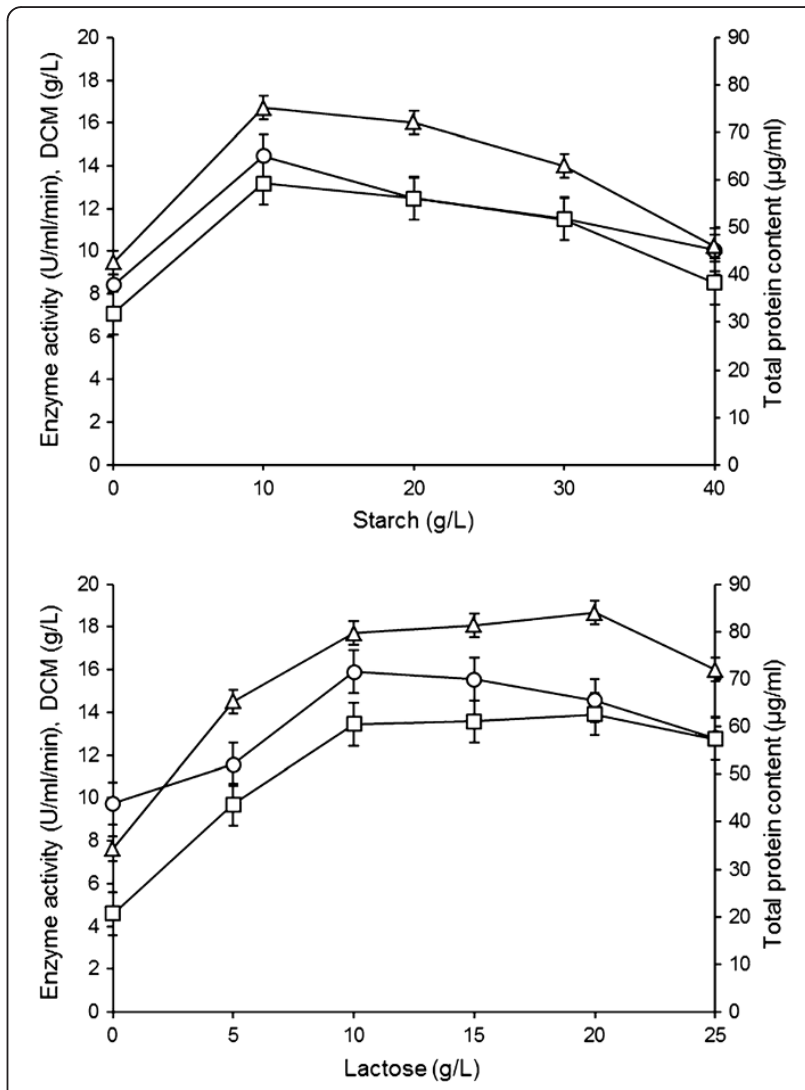

Figure 4 Effect of different concentrations of starch and lactose as carbon sources on GGH production by $A$. oryzae IIB-6.

Incubation were carried out for $72 \mathrm{~h}(200 \mathrm{rpm})$ at $30 \pm 2^{\circ} \mathrm{C}$ and $\mathrm{pH} 5$. Y-error bars indicate standard deviation $( \pm \mathrm{sd})$ among the three parallel replicates. - $\square$ - Enzyme activity (U/ml/min), -O- DCM (g/l), $-\Delta$ - Total protein content $(\mu \mathrm{g} / \mathrm{ml})$. 
optimized $40 \mathrm{~g} / \mathrm{l}$ starch concentration for enzyme production from fungal isolate $A$. fumigatus.

The lactose concentrations $(20 \mathrm{~g} / \mathrm{l})$ gave maximum enzyme production $(13.917 \pm 1.012 \mathrm{U} / \mathrm{ml} / \mathrm{min}, \mathrm{LSD} \sim 0.636)$. The mycelial morphology was observed as round pellets of intermediate sized. The protein content and DCM were $84.00 \pm 4.05 \mu \mathrm{g} / \mathrm{ml}(\mathrm{LSD} 2.712)$ and $14.56 \pm 1.24 \mathrm{~g} / \mathrm{l}$ (LSD 0.507), respectively. Other lactose concentrations (10 and $15 \mathrm{~g} / \mathrm{l})$ also induced relatively better enzyme production i.e., $13.461 \pm 1.511 \mathrm{U} / \mathrm{ml} / \mathrm{min}$ and $13.573 \pm 0.502$ $\mathrm{U} / \mathrm{ml} / \mathrm{min}$, respectively. However in contrast to our study, Singh and Soni (2001) used $10 \mathrm{~g} / \mathrm{l}$ lactose to stimulate enzyme production. Similar observations have also been made by Negi and Banerjee (2010) for amylase production by $A$. awamori. Some other workers (Vidya et al., 2012) used lactose at $30 \mathrm{~g} / \mathrm{l}$ concentration and found to be the best source for maximum amylase production.

The 2-factorial experimental system i.e., PlackettBurman design was applied to determine the significant process parameters involved in GGH production by the newly isolated mould culture of A. oryzae IIB-6 (Table 4). The validation of the model was investigated under the conditions predicted against the responses obtained for enzyme production. A differential correlation was noted between the observed and predicted values as reported by Burkert et al. (2006). The optimal levels of the parameters for improved enzyme production under submerged fermentation $(\mathrm{SmF})$ were incubation period $(72 \mathrm{~h})$, initial pH (5), CSL 6, yeast extract 9.5, starch 10 and lactose $20(\mathrm{~g} / \mathrm{l})$. The statistical analyses of the responses for enzyme production were also performed (Table 5). The correlation $(1.618 E+0025)$ of A, B, C, D and $\mathrm{E}$ for $\mathrm{F}$ values depicted that the model was highly significant (HS, $\mathrm{p} \leq 0.05)$. Correspondingly, the lower probability values indicated that the model terms are statistically valid. The analysis of linear, quadratic and interaction coefficients were performed on the batch culture results which highlighted that enzyme production was a function of the independent parameters (Ahuja et al. 2004) Lactose used as a sole carbon source (degree of freedom 3) has an important physiological role in the improvement of enzyme activity (Burkert et al. 2006). According to these results, the fungal strain of $A$. oryzae IIB-6 could be considered as an organism of choice for GGH productivity.

\section{Conclusions}

A soil-inhabited mould isolate $A$. oryzae IIB- 6 was identified as a hyper producer of 1,4- $\alpha$-D-glucan glucohydrolase $(\mathrm{GGH})$ in submerged fermentation $(\mathrm{SmF}) . \mathrm{M} 3$ as a basal medium gave better GGH yield at $30 \pm 2^{\circ} \mathrm{C}(200$ rpm). The cultural conditions such as $\mathrm{pH} 5$ and incubation period $(72 \mathrm{~h}$ ) were also optimized. Among the carbon and nitrogen sources, lactose $(20 \mathrm{~g} / \mathrm{l})$ and yeast extract $(9.5 \mathrm{~g} / \mathrm{l})$ raised the enzyme activity to a maximal of $13.91 \mathrm{U} / \mathrm{ml} / \mathrm{min}$. The values of kinetic variables, notably $\mathrm{Q}_{\mathrm{p}}\left(0.058 \pm 0.011^{\mathrm{a}} \mathrm{U} / \mathrm{ml} / \mathrm{h}\right), \mathrm{Y}_{\mathrm{p} / \mathrm{s}}\left(2.455 \pm 0.551^{\mathrm{a}} \mathrm{U} / \mathrm{ml} / \mathrm{g}\right)$ and $\mathrm{q}_{\mathrm{p}}\left(0.210 \pm 0.032^{\mathrm{abc}} \mathrm{U} / \mathrm{g}\right.$ fungal biomass/h) demonstrated that the isolated mould culture has a faster growth rate and subsequently a higher enzyme production capability (LSD 0.034). An overall improvement of more than $30 \%$ in terms of enzyme activity was accomplished when the significant process parameters were determined after PlackettBurman design. The value of correlation $(1.618 E+0025$ with dof $\sim 3$ ) depicted that the model terms are highly significant (HS, $\mathrm{p} \leq 0.05$ ). However, enzyme characterization is in progress prior to scale up studies.

\section{Methods}

The chemicals and reagents used in this study were of analytical grade and procured directly from Sigma (USA), BDH (UK) and Fluka (Switzerland).

Isolation and preliminary screening of mould cultures The soil samples were collected from various localities of Doha (Qatar) in sterilized polythene bags. Each

Table 4 Application of Plackett-Burman design at various process parameters (designated by different captions) for GGH production by $A$. oryzae IIB-6*

\begin{tabular}{|c|c|c|c|c|c|c|c|}
\hline \multicolumn{6}{|c|}{ Process parameters identified through 2-factorial design } & \multicolumn{2}{|c|}{ Enzyme activity(U/ml/min) } \\
\hline \multicolumn{2}{|c|}{ Cultural conditions } & \multicolumn{2}{|c|}{ Nitrogen sources } & \multicolumn{2}{|c|}{ Carbon sources } & \multirow[b]{2}{*}{ Observed } & \multirow[b]{2}{*}{ Predicted } \\
\hline Incubation period $(h)^{A}$ & Initial $\mathrm{pH}^{\mathrm{B}}$ & CSL conc. $(g / l)^{C}$ & Yeast extract $(g / l)^{D}$ & Starch conc. $(\mathrm{g} / \mathrm{l})^{\mathrm{E}}$ & Lactose conc. $(\mathrm{g} / \mathrm{l})^{\mathrm{F}}$ & & \\
\hline 24 & 4 & sna & 6.5 & sna & 5 & 6.252 & 8.245 \\
\hline 36 & 4.5 & 2 & 7.5 & sna & 10 & 8.654 & 9.558 \\
\hline 48 & 4.5 & 4 & 8.5 & 10 & 15 & 10.435 & 12.126 \\
\hline 72 & 5 & 6 & 9.5 & 10 & 20 & 13.917 & 13.756 \\
\hline 72 & 5.5 & 6 & 10 & 20 & 20 & 12.544 & 13.642 \\
\hline 84 & 6 & 8 & 10 & 30 & 25 & 11.006 & 10.865 \\
\hline
\end{tabular}

*The different letters represent significant process parameters for GGH fermentation. Statistical analysis of the model was based on 2-factorial experimental design. The abbreviation 'sna' means that specific nutritional source $(\mathrm{C} / \mathrm{N})$ was not added into the fermentation medium (M3). 


\begin{tabular}{|c|c|c|c|c|}
\hline Significant process parameters & Sum mean values & F-value & Degree of freedom & Probability $\langle\mathrm{p}>$ \\
\hline $\mathrm{A}$ & 4.133 & 7.628 & 1 & 0.078 \\
\hline B & 7.415 & 10.784 & 1 & 0.065 \\
\hline C & 8.768 & 12.105 & 1 & 0.057 \\
\hline D & 10.225 & 14.482 & 2 & 0.052 \\
\hline E & 12.688 & 15.295 & 3 & 0.034 \\
\hline $\mathrm{F}$ & 12.112 & 14.044 & 2 & 0.025 \\
\hline Correlation & $1.618 E+0025$ & & & \\
\hline
\end{tabular}

sample was diluted by serial dilution method. One millilitre of appropriately diluted soil suspension $\left(10^{-5}, 10^{-6}\right)$ was plated on starch agar medium $(10 \mathrm{~g} / \mathrm{l}$ raw corn starch, $1.496 \mathrm{~g} / \mathrm{K} \mathrm{KH}_{2} \mathrm{PO}_{4}, 1 \mathrm{~g} / \mathrm{l} \mathrm{MgSO}_{4} .7 \mathrm{H}_{2} \mathrm{O}, 1 \mathrm{~g} / \mathrm{l}$ $\mathrm{NaNO}_{3}, 20 \mathrm{~g} / \mathrm{l}$ agar, $\mathrm{pH} 4.8$ and sterilized at $121^{\circ} \mathrm{C}, 15$ lbs/in ${ }^{2}$ pressure for $15 \mathrm{~min}$ ) using pour plate method. The plates were incubated at $30 \pm 2^{\circ} \mathrm{C}$ for $72 \mathrm{~h}$ and subsequently flooded with iodine solution $(2 \mathrm{~g} / \mathrm{l}$ iodine, $4 \mathrm{~g} / \mathrm{l}$ potassium iodide prepared in deionized water). The zone of clearance around the microbial growth indicated GGH activity. The initial colonies of mould cultures showing bigger zones $\left(\sim 2 \mathrm{~mm}^{2}\right)$ of starch hydrolysis in the plates were picked up and transferred to potato dextrose agar (PDA) slopes ( $\mathrm{pH}$ 5.6) aseptically and then incubated at $30 \pm 2^{\circ} \mathrm{C}$ for $4-6$ days until optimal growth. The slant cultures were stored at $4^{\circ} \mathrm{C}$ in a mini cold lab (430D, Gallenkamp, London, UK) and renewed at least twice a month.

\section{Identification of mould isolates}

The fungal isolates were identified morphologically using a scotch tape of approximately $1 \mathrm{~cm}$ in length. The sticky end was placed over the fungal culture to pick up mycelia and other reproductive structures of fungi as reported by Harris (2000). It was placed upwards on a microscope slide. A drop of $0.5 \mathrm{~g} / \mathrm{l}$ trypan blue (prepared in lactophenol) was added. A coverslip was placed over the slide culture and then visualized at $40 \mathrm{X}$ under a compound microscope. The identified mould cultures were confirmed after (Onion et al. 1986).

\section{Inoculum preparation}

A volume of $10 \mathrm{ml}$ of sterilized $0.5 \mathrm{~g} / \mathrm{l}$ di-acetyl ester of sodium sulpho succinic acid (monoxal OT) were aseptically transferred to a slant culture having optimal conidial growth. The clumps of spores were broken with the help of a sterile inoculating wire loop. A homogeneous suspension was made by gently shaking the tube. The spore count was made by a haemocytometer (130M, Neubyeur, Munich, Germany) and found to be $1.2 \times 10^{7} \mathrm{CFU} / \mathrm{ml}$.

\section{Fermentation procedure and critical phases}

Shake flask fermentation technique was employed for 1,4- $\alpha$-D-glucan glucohydrolase (GGH) production under submerged fermentation $(\mathrm{SmF})$ technique. One milliliter spore suspension was transferred to the individual 250 $\mathrm{ml}$ Erlenmeyer flasks containing $50 \mathrm{ml}$ sterilized (at $121^{\circ} \mathrm{C}, 15-\mathrm{lbs} / \mathrm{in}^{2}$ pressure for $15 \mathrm{~min}$ ) M3 liquid medium (found optimal). The initial $\mathrm{pH}$ was adjusted to 5 . All the microbial fermentations were carried out in a rotary shaking incubator at $30 \pm 2^{\circ} \mathrm{C}, 200 \mathrm{rpm}$ for $72 \mathrm{~h}$. The experiments were run parallel in a set of three replicates.

\section{Fermentation media}

Following media were evaluated for GGH production during the course of study,

M1. $30 \mathrm{~g} / \mathrm{l}$ wheat bran 30, 1-L $0.01 \mathrm{~N} \mathrm{HCl}$, pH 4.6.

M2. $10 \mathrm{~g} / \mathrm{l}$ starch, $5 \mathrm{~g} / \mathrm{l}$ lactose, $10 \mathrm{~g} / \mathrm{l}$ nutrient broth, 2 $\mathrm{g} / \mathrm{l}\left(\mathrm{NH}_{4}\right)_{2} \mathrm{SO}_{4}, 2 \mathrm{~g} / \mathrm{l} \mathrm{CaCl} 2 \cdot 2 \mathrm{H}_{2} \mathrm{O}, 1-\mathrm{L}$ deionized water, pH 5.5.

M3. $20 \mathrm{~g} / \mathrm{l}$ starch, $10 \mathrm{~g} / \mathrm{l}$ lactose, $8.5 \mathrm{~g} / \mathrm{l}$ yeast extract, $6 \mathrm{~g} / \mathrm{l}$ corn steep liquor, $1.2 \mathrm{~g} / \mathrm{l} \mathrm{MgSO}_{4} \cdot 7 \mathrm{H}_{2} \mathrm{O}, 1.3 \mathrm{~g} / \mathrm{l}$ $\mathrm{NH}_{4} \mathrm{Cl}, 0.6 \mathrm{~g} / \mathrm{l} \mathrm{CaCl}_{2} \cdot 2 \mathrm{H}_{2} \mathrm{O}$, 1-L distilled water, $\mathrm{pH} 5$.

M4. $3 \mathrm{~g} / \mathrm{l}$ yeast extract, $20 \mathrm{~g} / \mathrm{l}$ peptone, $0.05 \mathrm{~g} / \mathrm{l}$ $\mathrm{MgSO}_{4} \cdot 7 \mathrm{H}_{2} \mathrm{O}, 0.2 \mathrm{~g} / \mathrm{l} \mathrm{CaCl} 2.2 \mathrm{H}_{2} \mathrm{O}, 0.1 \mathrm{~g} / 1 \mathrm{FeSO}_{4}$, 1-L phosphate buffer, $\mathrm{pH} 7.2$.

M5. $10 \mathrm{~g} / \mathrm{l}$ starch, $10 \mathrm{~g} / \mathrm{l}$ nutrient broth, $2.4 \mathrm{~g} / \mathrm{l}\left(\mathrm{NH}_{4}\right)$ ${ }_{2} \mathrm{SO}_{4}, 5 \mathrm{~g} / \mathrm{l} \mathrm{CaCl} 2.2 \mathrm{H}_{2} \mathrm{O}$, 1-L sodium acetate buffer, $\mathrm{pH} 6.4$.

\section{GGH isolation from fermented mash culture}

The fermented broth was filtered through an oven dried (at $102^{\circ} \mathrm{C}$ for $15 \mathrm{~min}$ ) pre-weighed Whatman filter paper No. 1. The mycelial morphology was observed. The clear filtrate was used for enzyme and protein assay, while cell mass was used to calculate dry weight.

\section{Determination of mycelial morphology}

Mycelial morphology was observed at macro level (Onion et al. 1986). Mycelia were categorized on the 
basis of their form and size as follow: Fine pellets (round clumps with diameters between 1-1.5 mm); small pellets (round clumps with diameters between 3-3.5 mm); intermediate pellets (round with diameters between 4$4.5 \mathrm{~mm}$ ); large pellets (round clumps with diameters between 6-6.5 $\mathrm{mm}$ ); mixed (a mixture of all previous four forms); viscous (a thick mixture of small and fine pellets with some free filaments); gelatinous (gel like mixture of fine pellets and filaments) and dumpy mass (irregular single mass with variable mycelial sizes).

\section{Analytical techniques}

The cell mass left in the pre-weighed filter paper was washed twice with distilled water and oven dried at $102^{\circ} \mathrm{C}$ for $2 \mathrm{~h}$. The dry cell mass (DCM) was calculated by subtracting the weight of filter paper from the final weight and converted to g/l. GGH was assayed according to the method of Caldwell et al. (1968). One millilitre of enzyme (diluted to $10^{-3}$ times) and $1 \mathrm{ml}$ of substrate $(50 \mathrm{~g} / \mathrm{l}$ Litner's soluble starch solution in $0.05 \mathrm{M}$ sodium acetate buffer, $\mathrm{pH}$ 5) was incubated at $60^{\circ} \mathrm{C}$ for $60 \mathrm{~min}$ with a constant stirring speed of 100 rpm. The amount of reducing sugar liberated was determined using 3, 5-dinitrosalicylic acid (DNS) reagent by measuring $A_{546 \mathrm{~nm}}$ on a spectrophotometer against glucose as the standard. "One unit of GGH activity was the amount of enzyme that liberates $1 \mathrm{mg}$ of reducing sugar (as glucose) under the specified assay conditions". The sugar released was then converted into $\mathrm{U} / \mathrm{ml} / \mathrm{min}$. Protein concentration was estimated in the filtrate by the method of Bradford (1976) with crystalline bovine serum albumin as the standard. The protein content was monitored by measuring $A_{595 \mathrm{~nm}}$.

\section{Secondary screening of isolated mould cultures by SmF technique}

Sixteen different mould cultures (coded as IIB-1 to IIB-16) of genera Aspergillus, Alternaria, Arthroderma, Fusarium, Trichoderma, Penicillium, Rhizopus and Chochlobolus spp. were screened for GGH production (Table 1). All the cultures were tested in triplicates by incubating the fermentation medium (M3 optimal) at $\mathrm{pH} 5,30 \pm 2^{\circ} \mathrm{C}, 200 \mathrm{rpm}$ for $72 \mathrm{~h}$.

\section{Parametric analysis by kinetic study}

Kinetic variables were studied according to the procedure of (Pirt 1975). The values for specific growth rate i.e., $\mu\left(h^{-1}\right)$ were calculated from the plots of $\ln (X)$ versus time of fermentation. The growth yield coefficient $\left(\mathrm{Y}_{\mathrm{x} / \mathrm{s}}\right)$ was calculated as the dry cell mass divided by the amount of saccharide utilized during the course of fermentation. The product yield coefficients namely $Y_{p / s}$ and $Y_{p / x}$ were determined by using the relationships $\mathrm{Y}_{\mathrm{p} / \mathrm{s}}=\mathrm{dP} / \mathrm{dS}$ and $\mathrm{Y}_{\mathrm{p} / \mathrm{x}}=\mathrm{dP} / \mathrm{dX}$, respectively. The volumetric rates for substrate utilization $\left(\mathrm{Q}_{\mathrm{s}}\right)$ and product formation $\left(\mathrm{Q}_{\mathrm{p}}\right)$ were determined from the maximum slopes in plots of substrate utilized and GGH produced versus the time of fermentation $(\mathrm{dt})$. The volumetric rate for biomass formation $\left(\mathrm{Q}_{\mathrm{x}}\right)$ was calculated from the maximum slope in a plot of cell mass formation versus incubation time period. The specific rate constants for product formation $\left(\mathrm{q}_{\mathrm{p}}\right)$ and substrate utilization $\left(\mathrm{q}_{\mathrm{s}}\right)$ were determined by the equations $q_{p}=\mu \times Y_{p / x}$ and $q s=\mu \times Y_{s / x}$, respectively. Further, the specific rate for cell mass formation $\left(\mathrm{q}_{\mathrm{x}}\right)$ was, calculated by multiplying the specific growth rate $(\mu)$ with the growth yield coefficient $\left(\mathrm{Y}_{\mathrm{x} / \mathrm{s}}\right)$.

\section{Determination of significant batch culture conditions}

Different fermentation media (M1, M2, M3, M4, M5) were evaluated for GGH production by $A$. oryzae IIB-6 (Table 3). All media were incubated at $30 \pm 2^{\circ} \mathrm{C}, 200 \mathrm{rpm}$ for $72 \mathrm{~h}$. The time course profile for GGH production in shake flasks was studied by incubating M3 medium. Incubation was carried out for $12-108 \mathrm{~h}$ at $30 \pm 2^{\circ} \mathrm{C}(200$ $\mathrm{rpm})$. The optimal initial $\mathrm{pH}$ for enzyme production was measured by incubating the fermentation medium for $72 \mathrm{~h}$ under a narrow $\mathrm{pH}$ range (4-6.5). The optimum concentrations of nitrogen and carbon sources were also investigated. The effects of different concentrations of CSL (2-10 g/l) and yeast extract (6.5-10 g/l) as nitrogen sources on GGH production were measured and compared with the control (run parallel). Different concentrations of starch (10-40 g/l) and lactose $(5-25 \mathrm{~g} / \mathrm{l})$ as carbon sources were employed to study their effects on enzyme production. The experiments of $\mathrm{C} / \mathrm{N}$ sources were conducted separately in triplicates at $\mathrm{pH} 5$ for $72 \mathrm{~h}$.

\section{Statistical analysis and application of Plackett-Burman experimental design}

Duncan's multiple range tests (Spss-16, version 9.5) were applied under one-way analysis of variance (I-ANOVA) and the treatment effects were compared after (Snedecor and Cochran 1980). Significance was presented in the form of probability $(\langle p>)$ values. The significant batch culture conditions affecting improved GGH productivity were identified using a 2-factorial system i.e., PlackettBurman experimental design (Ahuja et al. 2004) The variables were denoted at two widely spaced intervals and the effect of individual parameters on enzyme production was calculated by the following equations,

$$
\begin{aligned}
& E_{0}=\left(S M_{+}-S M_{-}\right) / N \\
& E=b_{1}+S B_{2}+S B_{3}+b_{123}
\end{aligned}
$$

In Eq. $I, E_{o}$ is the effect of first parameter under study while $\mathrm{M}+$ and $\mathrm{M}$ - are responses of enzyme by the selected fungal isolate. $\mathrm{N}$ is the total number of optimizations. In 
Eq. II, $E$ is the significant parameter, $\beta_{1}$ is the linear coefficient, $\beta_{2}$ the quadratic coefficient while $\beta_{3}$ is the interaction coefficient among significant process parameters.

\section{Abbreviations}

GGH: 1,4-a-D-glucan glucohydrolase; IIB: Institute of Industrial Biotechnology; CSL: Corn steep liquor; HS: Highly significant, dof, degree of freedom; SmF: Submerged fermentation; PDA: Potato dextrose agar; DCM: Dry cell mass; DNS: Dinitrosalicylic acid; ANOVA: Analysis of variance.

\section{Competing interests}

The authors declare they have no competing interests in relation to this article.

\section{Authors' contributions}

BF performed bench work; SA conceived the work. Both authors equally participated in the preparation of the manuscript, read and approved the final manuscript.

\section{Funding}

This research received no specific grant from any funding agency in the public, commercial or not-for-profit sectors.

\section{Acknowledgements}

We are extremely grateful to the Director IIB and Vice Chancellor for their contributions to promote research culture in the University.

\section{Received: 14 June 2012 Accepted: 2 October 2012}

\section{Published: 6 October 2012}

\section{References}

Abdalwahab SA, Ibrahim SA, Dawood ES (2012) Culture condition for the production of glucoamylase enzyme by different isolates of Aspergillus spp. Inter Food Res J 19(3):1261-1266

Ahuja SK, Ferreira GM, Morreira AR (2004) Application of Plackett-Burman design and response surface methodology to achieve exponential growth for aggregated shipworm bacterium. Biotechnol Bioeng 85:666-675

Arnthong J, Wanitchaploy B, Sakai K, Sanglier JJ, Kitpreechavanich V (2010) Statistical screening of factors affecting glucoamylase production by a thermotolerant Rhizopus microsporus TISTR 3518 using Plackett-Burman design. Afri J of Biotech 9(43):7312-7316

Bertolin TE, Schmidell W, Maiorano AE, Casara J, Costa JAV (2003) Influence of carbon, nitrogen and phosphorous sources on glucoamylase production by Aspergillus awamori in solid state fermentation. Z Naturforsch 58:708-712

Bradford MM (1976) A rapid and sensitive method for quantitation of microorganisms qualities of protein utilizing the principle of protein-dye binding. Anal Biochem 72:1105-1112

Burkert JFM, Kalil SJ, Filho FM, Rodrigues MI (2006) Parameters optimization for enzymatic assays using experimental design. Braz J Chem Eng 23:163-170

Caldwell KD, Roff A, Margereta B, Jerker P (1968) Estimation of glucoamylase. Biotech Bioeng 18:1592

Cherry HM, Hussain TM, Anwar MN (2004) Extracellular glucoamylase from isolate Aspergillus fumigatus. Pak J Biol Sci 17(11):1988-1992

Clementi F, Rossi I (1986) Alpha-amylase and glucoamylase production by Schwanniomyces castellii. Anton Von Lee 52:343-352

Gomes E, de Souza SR, Grandi RP Silva RD (2005) Production of thermostable glucoamylase by newly isolated Aspergillus flavus A1.1 and Thermomyces lanuginosus A13.37. Braz J Microbiol 36:75-82

Goto CE, Barbosa EP, Kistner LC, Moreira FG, Lenartovicz V, Peralta RM (1998) Production of amylase from Aspergillus fumigatus utilizing alpha-methyl-D-glycoside, a synthetic analogue of maltose, as substrate. FEMS Microbiol Lett 167:139-143

Harris JL (2000) Safe, low-distortion tape touch method for fungal slide mounts. J Clin Microbiol 38:4683-4684

Hyland K, Clayton PT (1992) Aromatic L-amino acid decarboxylase deficiency: diagnostic methodology. Clin Chem 38:2405-2410

Karaoglu SA, Ulker S (2006) Isolation, identification and seasonal distribution of soilborne fungi in tea growing areas of lyidere-kizdere vicinity. J Basic Microbiol 46:208-218

Kassim EA (1983) Effect of the physiological conditions on alpha-amylase and glucoamylase formation by a selected strain of Aspergillus oryzae. Mikrobiol 52:422-427

Kelly CT, Fogarty WM (1976) Microbial alkaline enzymes. Proc Biochem 11:3-9
Kumar P, Satyanarayana T (2007) Optimization of culture variables for improving glucoamylase production by alginate-trapped Thermomucor indicaeseudaticae using statistical method. Bioresour Technol 98:1252-1259

Kumar P, Satyanarayana T (2009) Microbial glucoamylases: characteristics and application. Crit Rev Biotechnol 29:225-255

Kumar S, Kumar P, Satyanarayana T (2007) Production of raw starch-saccharifying Thermostable and neutral glucoamylase by the thermophilic mold thermomucor indicae-seudaticae in submerged fermentation. Appl Biochem Biotechnol 142:221-230

Kunamneni A, Permaul K, Singh S (2005) Amylase production in solid-state fermentation by the thermophilic fungus Thermomyces lanuginosus. J Biosci Bioeng 100:168-171

Malik S, Iftikhar T, Haq I (2011) Process optimization for a potent wild and mutant strain of Aspergillus niger for biosynthesis of amyloglucosidsae. Pak J Bot 43:2211-2219

Michelena W, Castillo FJ (1984) Production of amylase by Aspergillus foetidus on rice flour medium and characterization of the enzyme. J Appl Bacteriol 56:395-407

Mishra A, Das DM (2002) Effect of pH on simultaneous saccharification and isomerization by glucoamylase and glucose isomerase. Appl Biochem Biotechnol 102:193-199

Morita H, Matsunaga M, Mizuno K, Fujio Y (1998) A comparison of raw starchdigesting glucoamylase production in liquid and solid cultures of Rhizopus strains. J Gen Appl Microbiol 44:211-216

Morya V, Yadav D (2009) Isolation and screening of different isolates of Aspergillus for amylases production. The Inter I of Microbiol 7(1):doi:10.5580/21f8

Nandi R, Mukherjee SK (1989) Effect of various organic compounds on synthesis of glucoamylase by an isolated strain Penicillium italicum. Ind J Exp Biol 27:1101-1102

Narayanan MS, Ambedkar SS (1993) Production, partial purification and characterization of amyloglucosidasefrom a new variety of Aspergillus candidus Link var. aureus. Hind Antibiot Bull Antibiot Bull 35:126-132

Negi S, Banerjee R (2010) Optimization of culture parameters to enhance production of amylase and protease from Aspergillus awamori in a single fermentation. Afri J of Biochem Res 4(3):73-80

Norouzian D, Akbarzadeh A, Scharer JM, Young M (2006) Fungal glucoamylases. Biotechnol Adv 24:80-85

Onion AHS, Allsopp D, Eggins OW (1986) Smith Introduction to Industrial Mycology. In: Fungal Morphology and Identification in Smith Introduction to Industrial Mycology, 7th edn. Edw Arn (Pub) Ltd, London, pp 187-188

Oshoma CE, Imarhiagbe EE, Ikenebomeh MJ, Eigbaredon HE (2010) Nitrogen supplements effect on amylase production by Aspergillus niger using cassava whey medium. Afr J Biotechnol 9:682-686

Pandey A, Nigam P, Soccol CR, Soccol VT, Singh D, Mohan R (2000) Advances in microbial amylases. Biotechnol Appl Biochem 31:135-152

Papagianni M (2004) Fungal morphology and metabolite production in submerged mycelial processes. Biotechnol Adv 22:189-259

Pirt SJ (1975) Specific Growth Coefficients in Principles of Microbes and Cell Cultivation, 2nd edn. Blackwell Scientific Corporation, London, p 116

Rangabhashiyam S, Sundari W, Hemavathy RV, Sankaran K (2011) Cosequece of copper ions on thermal stability of glucoamylase from aspergillus niger. Int $J$ Pharma Biosci 2:36

Razzaque A, Ueda S (1978) Glucoamylase of Aspergillus oryzae. J Ferment Technol 56:296-302

Rubinder K, Chadha BS, Singh N, Saini HS, Singh S (2002) Amylase hyperproduction by deregulated mutants of the thermophilic fungus Thermomyces lanuginosus. J Ind Microbiol Biotechnol 29:70-74

Shoji H, Sugimoto T, Hosoi K, Shibata K, Tanabe M, Kawatsura K (2007) Simultaneous Production of Glucoamylase and Acid-Stable a-Amylase Using Novel Submerged Culture of Aspergillus kawachii NBRC4308. Biosci Bioeng 103:203-205

Singh H, Soni SK (2001) Production of starch-gel digesting amyloglucosidase by Aspergillus oryzae HS-3 in solid-state fermentation. Proc Biochem 37:453-459

Snedecor GW, Cochran WG (1980) Biostat Applications in Statistical Methods, 7th edn. lowa State Univ Press lowa, Ames, pp 67-78

Vidya B, Gomathi D, Kalaiselvi M, Ravikumar G, Uma C (2012) Production and optimization of amylase from penicillium chrysogenum under submerged fermentation. World J of Pharma res 1(4):1116-1125

\section{doi:10.1186/2193-1801-1-32}

Cite this article as: Fatima and Ali: Kinetics of improved 1,4-alpha-Dglucan glucohydrolase biosynthesis from a newly isolated Aspergillus oryzae IIB-6 and parameter significance analysis by 2 -factorial design. SpringerPlus 2012 1:32. 